\title{
THE ETHNOPOLITICS ENTITIES - ORGANIZATIONS OF NATIONAL MINORITIES OF EASTERN EUROPEAN COUNTRIES
}

\author{
Magdalena Karolak-Michalska* (1) http://orcid.org/0000-0002-3282-654X
}

\begin{abstract}
Background. The increase in the complexity of the socio-political situation of Eastern European countries forces questions about the activity of ethnopolitics entities - national minority organizations. Difficult access to data makes it impossible to obtain precise answers to questions about the role of national minority organizations and the impact of their activities on the security of the region. Research interest in these organizations is timely, especially after the Crimean annexation in 2014.
\end{abstract}

Research aims. The aim is to define the role of national minority organizations in Eastern European countries in shaping the security of the subregion. The research area is: Belarus, Moldova and Ukraine. The author puts forward the following research questions: 1) What are the main factors determining the political and social activity of national minority organizations in the region? 2) Is it possible to distinguish the strategies of the studied organizations? 3) What is the essence of political activity of national minority organizations?

Methodology. An interdisciplinary research approach was applied, integrating methods from political science, international relations and management. The conclusions from author's own research carried out during foreign study trips in 2014-2017 were used. The literature has an interdisciplinary dimension.

Key findings. The role of national minority organizations in shaping the security of Eastern European states is diverse. Their activity will depend on the policy of the country of residence. Uncontrolled, they may lead to deepening of the security crisis in the region.

Keywords: ethnopolitics, national minority organizations, Russian minority, post-Soviet area, Eastern Europe.

JEL Codes: F52, F53, J71

* Department of Management and Security Sciences, University of Social Sciences, Łucka 11, 05-077 Warsaw. E-mail: mkarolak@spoleczna.pl 


\section{INTRODUCTION}

Analyzing the contemporary ethnopolitical situation of the countries of Eastern Europe (Belarus, Moldova and Ukraine), it is impossible not to refer to the organizations of national minorities, which constitute a space for building structures integrating the national community. Social activity in minority organizations unites "national or ethnic generations, conveys the characteristics of identity or consciousness, retains a common origin, unifies the minority community" (Knopek, 2002 , p. 80). In addition, as participants in the relationship between the state and other political entities and third sector organizations, they constitute a form of representation of their interests of an ethnocultural and ethno-political nature. It should be added that the extent to which members of the minorities feel the requirement of political activity corresponds with the sense of ethnic identity and is also determined by the existing legal order in a given country. Political activity is conditioned on the one hand by the opportunities determined by state institutions, and on the other one by bottom-up involvement of organizations gathering minorities (Kowalewska, 2015, p. 30).

When looking at minority organizations in the post-Soviet area (including, among others, those created by representatives of the Russian minority), it is impossible not to agree with prof. Andrzej Wierzbicki, that they can be seen as an example of a wider category of ethnopolitical organisms:

(...) encompassing all forms of organization of social life and their political institutions, including legal and political norms, as well as those shaped by the tradition and customs of social and social institutions (Wierzbicki, 2015, p. 54).

In the countries surveyed, the most intense activity of minority organizations is visible in Ukraine, while in Moldova and Belarus, although the intensity of the activity is smaller, it also takes on real shape. The interest in national minority organizations in the post-Soviet states is of current character, while it has definitely gained importance as a result of the Crimean annexation in 2014 and the ongoing war in Donbass. Discussions started in which questions were asked about the organizations' activity and their role in the transformation process 
of the Eastern European countries, as well as their impact on the security of the subregion.

\section{PRACTICE OF THE FUNCTIONING OF NATIONAL MINORITY ORGANIZATIONS IN THE SUBREGION - DETERMINANTS, STRATEGIES AND POLITICAL ACTIVITY}

In order to determine the specificity of the functioning of national minority organizations in Eastern European countries, it is first necessary to refer to the factors determining their activity. By building a catalog of determinants one can see that on the one hand it is multi-faceted (contains historical, cultural and social, demographic, economic and political dimensions), and on the other, it is possible to distinguish a kind of "skeleton" of groups of factors that specifically condition functioning and activity of the organizations*:

- institutional and legal conditions (regulations of national and international law, including the protection of minority rights),

- a sense of the national identity of a given minority (expressed, among others, in the use of the mother tongue) and the desire to mark its identity in the society of the country of residence,

- human resources of the organization (leaders, organizational and mobilization skills of members, setting goals and cooperation of the organization, degree of dispersion / territorial concentration of the organization's members),

- material resources (financial resources and their sources as well as access to them, equipment and premises),

- internal environment (relation to the titular nation, stereotypes about minority groups, relations with authority institutions, churches, religious associations, political parties and non-governmental organizations),

* Due to the lack of access to statistics on the number of minority organizations, it can be estimated on the basis of the literature and own research that out of the studied countries the most organizations appear in Ukraine, then in Moldova and Belarus. The report data The State and Dynamics of Development of Non-governmental Organizations of Ukraine 2002-2010 shows that 1\% of non-governmental organizations in Ukraine were registered until 1990, 24\% in 1995-1999, 35\% in 2000-2004, and 34\% after 2005. The number of organizations has been systematically growing in recent years (as of 2010, p. 23). 
- external environment (international relations, the whole relationship between the state of residence and the historical homeland) (Kowalewska, 2015, p. 43).

The role of the above factors is significant. They greatly translate into the selection of strategies for minority organizations in Eastern European countries. These, in turn, are diverse and each of them reflects the transformations of changes in the activity of the minorities themselves and the ethnologies of the countries of Eastern Europe.

Analyzing the activity of minority organizations in Eastern Europe countries, it can be seen that most of them are a part of one of 4 strategies: (1) ethnic (national) organic work; (2) civic treatment of minorities; (3) a strategy for cooperation and going outside; (4) being a "minority in the majority" (table 1). It should be added that:

(...) the organization's political needs are the motive for collective action resulting from the situational conditioning of the socio-cultural circle that creates these organizations (Kacperczyk, 2007, p. 50).

Author's research from 2014-2017 as well as the analysis of programs of the organizations indicate that these strategies often change, are not durable, have a combined nature and their assumptions overlap. Comparing the program objectives of organizations representing the interests of individual minorities leads to the conclusion that they show significant similarities, but at the same time they retain their specificity of operation. The common denominator for these organizations is the development of culture and mother tongue, the protection of cultural rights of minorities and the development of cooperation with the "historical fatherland" in various spheres (cultural, economic or political, depending on the country in which the minority lives). It should be made clear that among the minority organizations of the subregion there is a visible division into ethno-political and ethno-cultural organizations - for example, Russian organizations in Belarus and Moldova - unlike those that operate in Ukraine - mostly do not refer to economic issues, focusing on ethnocultural purposes in their programs (e.g. Powszechne Stowarzyszenie Rosyjski Ośrodek Kultury "Ruś"; Kiszyniowskie Stowarzyszenie Rosjan). In turn, organizations operating in Ukraine are in favor of the development of Ukrainian-Russian political and economic cooperation (e.g. Rosyjski Ruch Ukrainy). Importantly, the activities of these organizations are mainly focused on the particular needs of minorities, while issues of 
Table 1. Main strategies of political activity of (organizations of) national minorities in the countries of Eastern Europe

\begin{tabular}{|c|c|c|c|}
\hline $\begin{array}{l}\text { Name of the } \\
\text { strategy }\end{array}$ & $\begin{array}{c}\text { Characteristics of the } \\
\text { strategy }\end{array}$ & Country & Examples of organizations \\
\hline \multirow{3}{*}{$\begin{array}{l}\text { Ethnic } \\
\text { (national) } \\
\text { organic work }\end{array}$} & \multirow{3}{*}{$\begin{array}{l}\text { Striving to maintain and } \\
\text { develop culture through } \\
\text { the work and commitment } \\
\text { of its own members; } \\
\text { popularization of national } \\
\text { traditions and culture; } \\
\text { own social activity, with- } \\
\text { out waiting for help from } \\
\text { the state }\end{array}$} & Belarus & $\begin{array}{l}\text { Mińskie Towarzystwo Kultury } \\
\text { Rosyjskiej "Ruś"; Białoruskie } \\
\text { Stowarzyszenie Powszechne } \\
\text { "Ruś" }\end{array}$ \\
\hline & & Moldova & $\begin{array}{l}\text { Towarzystwo Malarzy } \\
\text { Rosyjskich "M-ART" }\end{array}$ \\
\hline & & Ukraine & $\begin{array}{l}\text { Centrum Kultury Rosyjskiej } \\
\text { "Cyrylica"; Zwiazek Prawo- } \\
\text { sławnych Obywateli Ukrainy }\end{array}$ \\
\hline \multirow{3}{*}{$\begin{array}{l}\text { Civic } \\
\text { treatment of } \\
\text { minorities }\end{array}$} & \multirow{3}{*}{$\begin{array}{l}\text { The state-oriented strate- } \\
\text { gy, the leaders of minority } \\
\text { organizations stress the } \\
\text { necessity / demand that } \\
\text { the state exercise its } \\
\text { rights, and expect the } \\
\text { demands they submit with } \\
\text { seriousness }\end{array}$} & Belarus & $\begin{array}{l}\text { Republikańskie Publiczne } \\
\text { Stowarzyszenie "Wspólnota } \\
\text { Rosyjska" }\end{array}$ \\
\hline & & Moldova & $\begin{array}{l}\text { Ogólnokrajowa Zjednoczona } \\
\text { Rada Szkół Rosyjskich; Kon- } \\
\text { gres Organizacji Rosyjskich } \\
\text { Republiki Mołdawii; Rosyjskie } \\
\text { Zjednoczenie Duchowe }\end{array}$ \\
\hline & & Ukraine & $\begin{array}{l}\text { Kulturowo-Rosyjska Wspólnota } \\
\text { w Kijowie; Charkowska Ob- } \\
\text { wodowa Organizacja } \\
\text { "Za Równość Kulturowo- } \\
\text {-Językowa"; Rosyjska Ruch } \\
\text { Ukrainy }\end{array}$ \\
\hline \multirow{3}{*}{$\begin{array}{l}\text { Strategy for } \\
\text { cooperation } \\
\text { and going } \\
\text { outside }\end{array}$} & \multirow{3}{*}{$\begin{array}{l}\text { Active inclusion of minori- } \\
\text { ties in the social and polit- } \\
\text { ical life of the region and } \\
\text { the country it inhabits, as } \\
\text { part of the activities car- } \\
\text { ried out by the minority }\end{array}$} & Belarus & $\begin{array}{l}\text { Białoruskie Stowarzyszenie } \\
\text { Powszechne "Ruś" }\end{array}$ \\
\hline & & Moldova & $\begin{array}{l}\text { Stowarzyszenie Rosjan } \\
\text { w Bielcach; Stowarzyszenie } \\
\text { Rosjan Republiki Mołdawii }\end{array}$ \\
\hline & & Ukraine & $\begin{array}{l}\text { Kongres Rosyjskich Organiza- } \\
\text { cji Krymu; Rosyjska Wspólnota } \\
\text { Dniepropietrowska }\end{array}$ \\
\hline \multirow{3}{*}{$\begin{array}{l}\text { Being } \\
\text { a "minority" } \\
\text { in the } \\
\text { majority }\end{array}$} & \multirow{3}{*}{$\begin{array}{l}\text { Maintaining the distinc- } \\
\text { tiveness without arousing } \\
\text { negative associations } \\
\text { among the titular nation; } \\
\text { exercising all the rights of } \\
\text { the majority }\end{array}$} & Belarus & $\begin{array}{l}\text { Zjednoczenie Nauczycieli } \\
\text { Języka i Literatury Rosyjskiej; } \\
\text { Białoruskie Powszechne } \\
\text { Stowarzyszenie Nauczycieli } \\
\text { Języka Rosyjskiego }\end{array}$ \\
\hline & & Moldova & $\begin{array}{l}\text { Stowarzyszenie Pisarzy Rosyj- } \\
\text { skich Republiki Mołdawii; Dom } \\
\text { Muzyki Rosyjskiej w Mołdawii }\end{array}$ \\
\hline & & Ukraine & $\begin{array}{l}\text { Organizacja Społeczna Szkoła } \\
\text { Rosyjska }\end{array}$ \\
\hline
\end{tabular}

Source: author's own elaboration based on: Łodziński, 2005, p. $264 \mathrm{ff}$. 
democratization and building a civil society in Belarus, Moldova and Ukraine are on the sidelines. However, this does not exclude the lack of influence of the organization's goals on the security of the region for example, the Rosyjska Wspólnota Krymu has been proclaiming the return of the Crimean peninsula to Russia since the early 1990s, and in 2014 supported the actions of the Russian authorities related to annexation.

Organizations accepting different strategies and acting in the ethnopolitical or ethno-cultural nature of the activity have specific functions. One can risk the statement that they most often take the following forms:

- cultural (caring for national identity, culture and mother tongue),

- $\quad$ social (including actions for the integration of minorities),

- political (articulating interests and representation of minorities in the authorities).

Importantly, these functions interpenetrate, often taking on a complementary character.

It is important that not all minorities living in Eastern European countries are equally involved in political activity, moreover, in the minority organizations themselves there is a diverse need for political representation. This is, among others, the result of such factors as: (1) the availability of financial assistance from home countries; (2) the minority's relation to the country of origin; (3) the relation of minorities to national culture; (4) opportunities to join and cooperate with international minority organizations. On the other hand, the willingness to participate in minority organization policy may depend on internal conditions in the country of residence: a) the size of the minority, its location and distribution and its proportion to the general public in the host country; b) relations between the majority and minority, resulting from: their historical and present relationships, institutional and legal possibilities of influencing political solutions at the central and local level, including the creation of separate group rights for categories of citizens with a different ethnic or national identity by the state (Kowalewska, 2015, pp. 38-39; Bojar, 1991, pp. 403-418). It should be remembered that the stronger the minority's aspirations to strengthen its position in relations with titular and other ethnic groups, to obtain social privileges, and finally to strengthen its influence in 
other spheres, the stronger the motivation of minorities to ensure their participation in socio-political, economic and cultural life of the subregion countries. At the same time, it is important that the organizations of national minorities in Eastern European countries arise in conditions of weakly rooted traditions of civil society and self-organization of the public sphere.

Pondering on the issue of political activity of national minorities in the subregion, it can also be seen that it can be considered in three dimensions:

a) symbolic (ritual) vs. real impact - in this sense some of the activities of a civil act of courage or a certain moral attitude can be described as "apolitical"; b) conventional vs. unconventional action - defined by the constitutional and institutional framework within the limits of the legal order and direct actions, having the character of legal or illegal forms of influencing the government; c) activities of varying intensity (differentiated in relation to such features as repeatability, involvement of participants). Importantly, these dimensions can interpenetrate each other, which means that a certain form of political activity can be described, for example, as an incidental symbolic action having a conventional character (Skarżyńska, 2002, p. 27).

Research observations of the political activity of minority organizations in Eastern European countries indicate that it has a diverse and multi-layered nature. The most frequent practices include: active and passive participation in elections (e.g. since Belarus, Moldova and Ukraine gained independence, the Russian minority has had their representatives in the parliaments of these countries), organizing political support (e.g. during political demonstrations and also promoting leaders, including minorities, and their political programs), or participation in a public debate on an ethnic issues, e.g. Russians belonging to the parliamentary Committee on Human Rights, National Minorities and Interethnic Relations - became co-authors 32 legal projects in the years 2007-2009 (Wierzbicki \& Karolak-Michalska, 2016 , pp. 245-256). The above forms of activity have various functions, both for the represented minority and for the political system of Belarus, Moldova and Ukraine. It should be added that the activity undertaken by the organizations can be described as an enclave-type (in the scale of the whole society, e.g. Rosyjski Ruch Ukrainy), while forms of political and civic activity such as belonging to an organization 
or voting on ethnic parties should be referred to as empirical activity (e.g. Rosyjska Wspólnota Krymu)*.

The political and social activity of minority organizations in Eastern European countries also points to their strengths and weaknesses. The former include, among others: (1) protection of minority rights and their enforcement; (2) strengthening the integration of minorities; (3) caring for national identity, linguistic and cultural separateness. In turn, the catalog of weaknesses - limiting the effectiveness of the organizations - is formed by: a) shaping a negative image of a minority in the country of residence; through its dysfunctional activities; b) lack of human and material resources; c) competition; d) conflicts within the organization that affect the lack of subsequent initiatives. In addition, analyzing the specificity of the activities of national minority organizations in Eastern European countries, one can see the reality of their formation, break-up or merging, in which they often compete with each other for the exclusive right to represent a given minority (e.g. Polish minority in Belarus). It is worth noting here that in order to increase the efficiency of operations, each of the minority organizations in the sub-regional countries should provide itself with answers to a number of questions, including whether they have the possibility to influence changes. What is, and what could be, the participation of organizations in the processes of modernization of the local environment? Does it want to participate actively and in an organized way in local development processes? Can the political ideology of the organization count on the support of other local communities or political groups? What do we expect from the authorities? (Kowalewska, 2015, p. 42; Mizgalski, 2012, pp. 68-69).

Piotr Gliński and Hanna Palska distinguish following forms of social civic activity: verbal (form of deliberation and citizen readiness), potential (form of declarative support for institutions representing civic interests), enclave-type (takes place in partially isolated areas of social life, e.g. within the third sector), empirical (examined by means of surveying measurement tools in which, among others, declarations of participation in organizations or political parties are measured) (Gliński \& Palska, 1997, pp. 366-368). 


\section{ACTIVITIES OF NATIONAL MINORITY ORGANIZATIONS AND THE SECURITY OF THE SUBREGION}

Looking at the activities of national minority organizations in Eastern European countries, it is clear that not all of them have a real impact on the security level in the subregion or are an important factor to consider when formulating the national security strategies. What is important, from the own research carried out in the subregion in 2010-2017, it is clear that the Russian minority is particularly active in comparison with other minorities in Belarus, Moldova and Ukraine and forms the most numerous ethno-political and ethno-cultural organizations. In Ukraine, the activity of Russians is greater in relation to Belarusians, Romanians and Jews. For example, the leader among local organizations - Rosyjski Ruch Ukrainy - initiates regional conferences, national conventions and round tables. In-depth studies in the subregion indicate that from the early 1990s the Russian minority in the former USSR countries, driven by the desire to develop their own culture and traditions, participate in power, be aware of the expectations and interests of the Russian population and the sense of their threat, as well as ethnocultural and ethno-social stratification coinciding with the regional socio-economic diversity, it assumed political parties and non-governmental organizations.

The events of the Crimea annexation of 2014 particularly highlighted the attention of researchers on the Russian minority (the largest in the Ukrainian territory $-17.3 \%$ of the total) and its organizations, as well as the role they play in formulating national security. It was the Russians living on the peninsula that became the direct cause of the changes. The war in Donbass, ongoing since 2014, brought shock, which translated into to increase awareness of the distinctiveness of Ukrainian identity and culture from the Russian one, but also to the ethnopolitical goals of the Russian minority, which have been voiced since the early 1990s and still exist in the programs of its organizations (including state status for the Russian language, change in the legal status of the Russian minority, development of Ukrainian-Russian cooperation, counteraction of Ukraine's accession to NATO, federalisation of Ukraine are the slogans of the Kharkiv organization $\mathrm{Za}$ Równość Kulturowo-Językowa, Odessa Regional Organization “Jedna 
Ojczyzna”, Spadkobiercy Bogdana Chmielnickiego) (Wierzbicki \& Karolak-Michalska, 2016, pp. 307-324). In turn, the Russian minority in Belarus (8.3\% of the total in 2009), as compared to national groups, also occupies an "exceptional" position - in 1989-2017 none of the other minorities matched its number (Nacional'nyj..., 2009). The Russians form clusters all over Belarus, with a clear advantage in the eastern part of the country. The specificity of the activity of the organization of the Russian minority in Belarus focuses on the events of the Crimean annexation. Some of the organizations - although they are mostly of an ethno-cultural nature and emphasize activities in the field of culture (e.g. Republikańskie Publiczne Stowarzyszenie "Rosyjska Wspólnota"), expressed their satisfaction with the referendum in the Crimea and the protection of the Russians there by their "historical homeland" in the form of the so-called support marches (e.g. Koordynacyjna Rada Organizacji Rosyjskich Sooteczestwennikow). In addition, pro-Russian organizations that perceive Belarus as part of the Russian World have been active in most of the regions*.

Also in Moldova, Russians living in the conditions of multilingualism and multiculturalism have a significant demographic position $(4.1 \%$ of the general population). They occupy a special place in Transnistria, where they constitute $30.4 \%$ of the region's population (Moldovans - 31.9\%, Ukrainians - 28.8\%) (Pridniestrovie, 2013). In the context of the Ukrainian-Russian crisis, Moldova fears that it may have problems with the Russian minority that Ukraine currently has. The reason for this is the lack of a solution to the political conflict about Transnistria - the region of Moldova, which has virtually detached itself from the state and is controlled by Russia. In Transnistria, the news about the annexation of Crimea caused the satisfaction of the majority of Russian political circles, among the leaders of the Russian minority organization and also strengthened the activity of some organizations representing the interests of the Russian population, which was evident, among others, as part of organized rallies or marches (e.g. Kongres Organizacji Rosyjskich Mołdawii, "Nasze Pokolenie") (Mołdawia..., 2014).

According to current research, the annexation of Crimea has become a stimulus for the Russian minority in Transnistria to return the region

This concept goes beyond the borders of Russia and Russian ethnos. The core of the Russian World are the Russians and other nations are in their orbit. 
to the "historical homeland", as well as to expand the list of their rights and work to achieve their goals (development of Russian language and culture, activity publishing, development of Russian education, protection of the rights of the Russian-speaking population and the Russian language, Moldavian-Russian cooperation, popularization of Russian patriotism among Russian youth) and numerous demonstrations, rallies and marches in which they proclaim postulates and pro-Russian slogans (Organizacii 2018).

The clusters of the Russians in the countries of Eastern Europe naturally became the space in which the separatist tendencies began to emerge. It should be added that the Russians in the former USSR republics the participate in the socio-political and economic life of individual states. The organizational activity of the Russians favors political mobility, it is also a manifestation of the lack of consent for assimilation. It stimulates the development of the ethnicity of the Russian population, and also builds a bond between the Russians in specific territories. In addition, by giving the Russian minority a sense of separation from the titular nations, it deepens cultural differences in society, which become one of the grounds of national conflicts, and thus they become a threat to the security of the subregion.

It can be assumed that the ethnopolitical movements of the Russian minority in the post-Soviet area will be even more strongly opposed to discrimination against the Russian population and to fight for its rights more actively. The annexation of the peninsula, the sense of danger caused by internal conflicts in the republics, as well as the widespread failure of systemic changes and the depreciation of the Russians have become additional pretexts for the mobilization of Russians in the territory of the former USSR. At the same time, it points out that in the majority the organizations of the Russian minority (except for radical communities), monitoring its situation in a given country, focus primarily on the particular needs of the Russian and Russian-speaking population, leaving issues related to the return to Russia the lands they live on aside or treating them as secondary. In turn, in radical milieus representing the interests of the Russian minority, the annexation strengthened the separatist tendencies, as exemplified by Transnistria, which at the same time combines with the threat to Moldovan security. 


\section{CONCLUSION}

The role of national minority organizations in shaping the security of Eastern European states is diverse, from insignificant (in the case of small organizations focusing only on ethnocultural goals whose demographic potential in a given country is marginal, e.g. the Ukrainian minority in Belarus - about $1.7 \%$ of the total), to significant, in the case of the Russian minority, whose potential and political activity in Ukraine became the direct cause of the Crimean annexation.

The current activity of the Russians in the post-Soviet area suggests that they will continue to work to achieve their goals, this activity (including the separatist one) will depend on the internal policy (especially the ethnopolitics) of the authorities of the state they live in, as well as the Kremlin's policy towards its compatriots abroad. It is evident that:

although Russia recognized the independence of the former Soviet republics, it did not lose its sense of the imperial power and did not remove imperial ambitions from the "near abroad" region - the best example of which is the annexation of Crimea (Pipes, 2002, pp. 17-18).

It should also be remembered that representatives of the Russian minority, especially those active in political parties and non-governmental organizations, take high positions in the social, economic, political and cultural structure of post-Soviet states. They are also active in business sectors, which gives Russia the stock of human capital to use to pursue the interests of its internal and foreign policy. The neo-imperial slogans, which are gaining strength in the organizations of the Russian minority, require constant monitoring by the authorities of the countries of Eastern Europe. Their implementation - in the face of the ongoing war in Donbass - not only threatens the security of the subregion, but may lead to a significant deepening of the security crisis in the subregion.

\section{REFERENCES}

Bojar, H. (1991). Mniejszości narodowe - nowe formy uczestnictwa w życiu III Rzeczypospolitej. In: H. Domański, A. Rychard (red.). Elementy nowego tadu (pp. 403-418). Warszawa: IFiS PAN. 
Gliński, P. \& Palska, H. (1997). Cztery wymiary społecznej aktywności obywatelskiej. In: H. Domański, A. Rychard (red.). Elementy nowego ładu (pp. 356-392). Warszawa: IFiS PAN.

Kacperczyk, A. (2007). Społeczne światy i areny a problem zmiany organizacyjnej. In: K. Konecki, P. Chomczyński (red.). Zarzadzanie organizacjami. Organizacja jako proces (pp. 43-53). Łódź: Wyd. Uniwersytetu Łódzkiego.

Knopek, J. (2002). Przedstawiciele życia organizacyjnego i społecznego na Pomorzu. Szkic o mniejszości greckiej. In: A. Chodubski, A.K. Waśkiewicz (red.). Tożsamość kulturowa. Szkice o mniejszościach narodowych na Pomorzu Gdańskim (pp. 80-85). Gdańsk: Wyd. Marszałek.

Kowalewska, D. (2015). Organizacje mniejszości narodowych i etnicznych jako podmioty etnopolityki. Zeszyty Naukowe Uniwersytetu Szczecińskiego, $889,27-47$.

Łodziński, S. (2005). Równość i różnica: mniejszości narodowe w porzadku demokratycznym w Polsce po 1989 roku. Warszawa: WN Scholar.

Mizgalski, J. (2012). Tożsamość polityczna partii / ugrupowania politycznego w lokalnej przestrzeni politycznej. In: J. Mizgalski, J. Sielski (red.). Res Politicae (pp. 65-97). Częstochowa: Wyd. AJD.

Mołdawia tė̇ ma problem z rosyjska mniejszościq (2014). https://www.tvp.info/14241566/ informacje/swiat/moldawia-tez-ma-problem-z-rosyjska-mniejszoscia/?captcha_ key= (accessed: 11th May 2017).

Nacional'nyj Sostav Nasieleniâ (2009). www.belstat.gov.by (accessed: 12th July 2018).

Obŝestvennyje organizacii sootečestvennikov v stranah SNG i Pribaltiki (2017). www. zatulin.ru (accessed: 12th Aug 2018).

Organizacii Sootečestvennikov za rubežom. Belorus' (2017). www.blr.rs.gov.ru (accessed: 12th Aug 2018).

Organizacii Sootečestvennikov za rubežom. Moldoviâ (2017). www.materik.ru (accessed: 12th Aug 2018).

Pipes, R. (2002). Przeszłość i przyszłość Rosji. In: R. Pipes (red.). Rosja, komunizm $i$ świat. Wybór esejów. Tłum. A. Nowak, S. Czarnik. Kraków: Świat Książki. Pridniestrovie (2013). www.pridnestrovie.net (accessed: 12th Aug 2018).

Russkie organizacii za rubežom (2017). www.materik.ru (accessed: 20th Sep 2018). Skarżyńska, K. (2002). Aktywność i bierność polityczna. In: K. Skarżyńska (red.). Podstawy psychologii politycznej (pp. 21-50). Poznań: Zysk i S-ka.

Stan ta dinamika rozvitku neurâdovih organizacii Ukraïni 2002-2010 roki (2010). Kijów: Centrum im. Razumkowa.

Wierzbicki, A. \& Karolak-Michalska, M. (2016). Mniejszość rosyjska w etnopolityce państw Europy Wschodniej i Azji Centralnej. Warszawa: Wyd. WDiNP UW. 
Wierzbicki, A. (2015). Genetyczno-kulturowe podstawy etnopolityki. Perspektywa etnonacjonalistyczna. In: H. Chałupczak et al. (red.). Polityka etniczna. Teorie, koncepcje, wyzwania (pp. 51-69). Lublin: Wyd. UMCS.

\section{APPENDIX}

Table 2. The objectives of the major non-governmental organizations representing the interests of the Russian minority in Eastern European countries in the years 1991-2018

\begin{tabular}{|c|c|c|}
\hline Organization & Types & Goals \\
\hline \multicolumn{3}{|c|}{ BELARUS } \\
\hline $\begin{array}{l}\text { Zjednoczenie Nauczycie- } \\
\text { li Jezzyka i Literatury } \\
\text { Rosyjskiej }\end{array}$ & Ethnocultural & $\begin{array}{l}\text { Development of Russian language and cul- } \\
\text { ture; protection of Russian minority's rights; } \\
\text { development of Russian language in Belarus } \\
\text { education system; Ukrainian-Russian cooper- } \\
\text { ation for the benefit of Russian language and } \\
\text { culture }\end{array}$ \\
\hline $\begin{array}{l}\text { Białoruskie Powszechne } \\
\text { Stowarzyszenie Nauczy- } \\
\text { cieli Języka Rosyjskiego }\end{array}$ & Ethnocultural & $\begin{array}{l}\text { Education activity for the benefit of Russian } \\
\text { language; establishment of scientific and } \\
\text { research cooperation between Belarus and } \\
\text { Russia }\end{array}$ \\
\hline $\begin{array}{l}\text { Białoruskie Powszechne } \\
\text { Stowarzyszenie "Ruś" }\end{array}$ & Ethnocultural & $\begin{array}{l}\text { Protection of Russian minority's rights; } \\
\text { promoting Russian language and culture; } \\
\text { enhancing Russian-Belarusian friendship }\end{array}$ \\
\hline $\begin{array}{l}\text { Witebskie Powszechne } \\
\text { Stowarzyszenie } \\
\text { "Rosyjski Dom" }\end{array}$ & Ethnocultural & $\begin{array}{l}\text { Development of Russian culture; promotion } \\
\text { of Russian language; protection of social and } \\
\text { cultural interests of Russian speaking popu- } \\
\text { lation in the Witebsk region }\end{array}$ \\
\hline $\begin{array}{l}\text { Koordynacyjna Rada } \\
\text { Przewodniczących } \\
\text { Organizacji Rosyjskich } \\
\text { Rodaków }\end{array}$ & Ethnocultural & $\begin{array}{l}\text { Protection of cultural, social and economic } \\
\text { interests of Russian minority }\end{array}$ \\
\hline $\begin{array}{l}\text { Mińskie Towarzystwo } \\
\text { Kultury Rosyjskiej } \\
\text { "Ruś" }\end{array}$ & Ethnocultural & $\begin{array}{l}\text { Protection of Russian minority's rights in } \\
\text { Belarus; development of Russian language } \\
\text { and culture }\end{array}$ \\
\hline $\begin{array}{l}\text { Powszechne } \\
\text { Stowarzyszenie Rosyjski } \\
\text { Ośrodek Kultury "Ruś" }\end{array}$ & Ethnocultural & $\begin{array}{l}\text { Protection of Russian minority's rights, } \\
\text { enhancing Russian-Belarusian cooperation in } \\
\text { the area of culture }\end{array}$ \\
\hline $\begin{array}{l}\text { Republikańskie } \\
\text { Powszechne } \\
\text { Stowarzyszenie "Bi- } \\
\text { ałoruski Zwiazek Liter- } \\
\text { atów" "Połacka Gałąź" }\end{array}$ & Ethnocultural & $\begin{array}{l}\text { Development and popularization of Russian } \\
\text { literature }\end{array}$ \\
\hline $\begin{array}{l}\text { Republikańskie Pub- } \\
\text { liczne Stowarzyszenie } \\
\text { "Wspólnota Rosyjska" }\end{array}$ & Ethnocultural & $\begin{array}{l}\text { Development of Russian tradition and cul- } \\
\text { ture; strengthening social and cultural bonds } \\
\text { between Russia and Belarus }\end{array}$ \\
\hline
\end{tabular}


Table 2. cont.

\begin{tabular}{|c|c|c|}
\hline Organization & Types & Goals \\
\hline $\begin{array}{l}\text { Białoruskie Powszechne } \\
\text { Stowarzyszenie "Ruś" }\end{array}$ & Ethnocultural & $\begin{array}{l}\text { Protection and development of Russian lan- } \\
\text { guage; uniting Russian population in Belar- } \\
\text { us; enhancing Russian-Belarusian friendship }\end{array}$ \\
\hline $\begin{array}{l}\text { Publiczne Stowarzysze- } \\
\text { nie "Białoruski Związek } \\
\text { Blokad Leningradu" }\end{array}$ & Ethnocultural & $\begin{array}{l}\text { Protection of social, economic and cultural } \\
\text { rights of Russian minority }\end{array}$ \\
\hline \multicolumn{3}{|c|}{ MOLDOVA } \\
\hline $\begin{array}{l}\text { Stowarzyszenie Pisarzy } \\
\text { Rosyjskich Republiki } \\
\text { Mołdowy }\end{array}$ & Ethnocultural & $\begin{array}{l}\text { Development of Russian language and } \\
\text { culture; protection of the works of Russian } \\
\text { painters; publishing activity }\end{array}$ \\
\hline $\begin{array}{l}\text { Związek Przed- } \\
\text { siębiorców Rosyjskich } \\
\text { Mołdowy }\end{array}$ & Ethnopolitical & $\begin{array}{l}\text { Protection of Russian speaking population's } \\
\text { rights; establishment of economic cooperation } \\
\text { between Russia and Moldova }\end{array}$ \\
\hline $\begin{array}{l}\text { Dom Muzyki Rosyjskiej } \\
\text { w Mołdawii }\end{array}$ & Ethnocultural & $\begin{array}{l}\text { Promoting Russian language and culture; } \\
\text { friendship between Russian and Moldovan } \\
\text { nations }\end{array}$ \\
\hline "Nasze Pokolenie" & Ethnocultural & $\begin{array}{l}\text { Publishing activity in Russian language; } \\
\text { cooperation with publishing centers in CIS } \\
\text { countries }\end{array}$ \\
\hline $\begin{array}{l}\text { Kiszyniowskie } \\
\text { Stowarzyszenie Rosjan }\end{array}$ & Ethnocultural & $\begin{array}{l}\text { Protection of Russian language and culture; } \\
\text { protection of Russian speaking population's } \\
\text { rights }\end{array}$ \\
\hline $\begin{array}{l}\text { Kongres Organizacji } \\
\text { Rosyjskich Republiki } \\
\text { Mołdowy }\end{array}$ & Ethnocultural & $\begin{array}{l}\text { Protection of Russian minority's rights; } \\
\text { development of Russian language; publishing } \\
\text { activity; support for Russian writers }\end{array}$ \\
\hline $\begin{array}{l}\text { Rada Koordynacyjna } \\
\text { Rosyjskich Rodaków }\end{array}$ & Ethnocultural & $\begin{array}{l}\text { Protection of Russian minority's rights, } \\
\text { development and popularization of Russian } \\
\text { language and culture }\end{array}$ \\
\hline $\begin{array}{l}\text { Liga Młodzieży } \\
\text { Rosyjskiej Republiki } \\
\text { Mołdowy }\end{array}$ & Ethnocultural & $\begin{array}{l}\text { Improvement of learning conditions for } \\
\text { Russian and Russian speaking youth; popu- } \\
\text { larization of Russian literature; cooperation } \\
\text { with Russian minority organizations in CIS } \\
\text { countries }\end{array}$ \\
\hline $\begin{array}{l}\text { Mołdawskie } \\
\text { Stowarzyszenie } \\
\text { Nauczycieli Języka } \\
\text { i Kultury Rosyjskiej }\end{array}$ & Ethnocultural & $\begin{array}{l}\text { Development of Russian science, language, } \\
\text { tradition and culture }\end{array}$ \\
\hline $\begin{array}{l}\text { Zjednoczona } \\
\text { Organizacja "Rus" }\end{array}$ & Ethnocultural & $\begin{array}{l}\text { Protection and development of Russian lan- } \\
\text { guage and culture }\end{array}$ \\
\hline $\begin{array}{l}\text { Stowarzyszenie } \\
\text { Rosjan Regionu } \\
\text { Wulkaneszckiego }\end{array}$ & Ethnocultural & $\begin{array}{l}\text { Protection and development of Russian lan- } \\
\text { guage and culture }\end{array}$ \\
\hline $\begin{array}{l}\text { Stowarzyszenie Rosjan } \\
\text { m. Komrat }\end{array}$ & Ethnocultural & $\begin{array}{l}\text { Protection of Russian language and culture; } \\
\text { protection of Russian speaking population's } \\
\text { rights }\end{array}$ \\
\hline $\begin{array}{l}\text { Stowarzyszenie Rosjan } \\
\text { m. Lipkany }\end{array}$ & Ethnocultural & $\begin{array}{l}\text { Protection of Russian speaking population's } \\
\text { rights; protection of Russian language and } \\
\text { culture }\end{array}$ \\
\hline
\end{tabular}


Table 2. cont.

\begin{tabular}{|c|c|c|}
\hline Organization & Types & Goals \\
\hline $\begin{array}{l}\text { Stowarzyszenie Rosjan } \\
\text { Gagauzii }\end{array}$ & Ethnocultural & $\begin{array}{l}\text { Protection of Russian language and culture; } \\
\text { protection of Russian speaking population's } \\
\text { rights }\end{array}$ \\
\hline $\begin{array}{l}\text { Stowarzyszenie Rosjan } \\
\text { Regionu Drokijewskigo }\end{array}$ & Ethnocultural & $\begin{array}{l}\text { Protection of Russian speaking population's } \\
\text { rights; protection of Russian language and } \\
\text { culture }\end{array}$ \\
\hline $\begin{array}{l}\text { Stowarzyszenie Rosjan } \\
\text { Regionu Edineckiego }\end{array}$ & Ethnocultural & $\begin{array}{l}\text { Protection of Russian language and culture; } \\
\text { support for "sootečestvennikov" and Russian } \\
\text { speaking population }\end{array}$ \\
\hline $\begin{array}{l}\text { Stowarzyszenie Rosjan } \\
\text { Regionu Kałaraszskiego }\end{array}$ & Ethnocultural & $\begin{array}{l}\text { Protection of Russian language and culture; } \\
\text { protection of Russian speaking population's } \\
\text { rights }\end{array}$ \\
\hline $\begin{array}{l}\text { Stowarzyszenie Rosjan } \\
\text { Regionu Kauszanskiego }\end{array}$ & Ethnocultural & $\begin{array}{l}\text { Protection of Russian speaking population's } \\
\text { rights, Russian language and culture }\end{array}$ \\
\hline $\begin{array}{l}\text { Stowarzyszenie Rosjan } \\
\text { Belcy }\end{array}$ & Ethnocultural & $\begin{array}{l}\text { Protection of Russian speaking population's } \\
\text { rights, Russian language and culture }\end{array}$ \\
\hline $\begin{array}{l}\text { Stowarzyszenie Rosjan } \\
\text { Regionu Oknickiego }\end{array}$ & Ethnocultural & $\begin{array}{l}\text { Protection of Russian speaking population's } \\
\text { rights, Russian language and culture }\end{array}$ \\
\hline $\begin{array}{l}\text { Stowarzyszenie Rosjan } \\
\text { Regionu Sztefan-Wode }\end{array}$ & Ethnocultural & $\begin{array}{l}\text { Protection of Russian speaking population's } \\
\text { rights, Russian language and culture }\end{array}$ \\
\hline $\begin{array}{l}\text { Stowarzyszenie Rosjan } \\
\text { Regionu Rezinskiego }\end{array}$ & Ethnocultural & $\begin{array}{l}\text { Protection of Russian speaking population's } \\
\text { rights, Russian language and culture }\end{array}$ \\
\hline $\begin{array}{l}\text { Stowarzyszenie Rosjan } \\
\text { Regionu Ryszkanskiego }\end{array}$ & Ethnocultural & $\begin{array}{l}\text { Protection of Russian speaking population's } \\
\text { rights, Russian language and culture }\end{array}$ \\
\hline $\begin{array}{l}\text { Stowarzyszenie Rosjan } \\
\text { Regionu Straszenskiego }\end{array}$ & Ethnocultural & $\begin{array}{l}\text { Protection of Russian speaking population's } \\
\text { rights, Russian language and culture }\end{array}$ \\
\hline $\begin{array}{l}\text { Stowarzyszenie Rosjan } \\
\text { Regionu Ungenskiego }\end{array}$ & Ethnocultural & $\begin{array}{l}\text { Protection of Russian speaking population's } \\
\text { rights, Russian language and culture }\end{array}$ \\
\hline $\begin{array}{l}\text { Stowarzyszenie Rosjan } \\
\text { Regionu Faleszckiego }\end{array}$ & Ethnocultural & $\begin{array}{l}\text { Protection of Russian speaking population's } \\
\text { rights, Russian language and culture }\end{array}$ \\
\hline $\begin{array}{l}\text { Stowarzyszenie Rosjan } \\
\text { Regionu } \\
\text { Chynczesztskiego }\end{array}$ & Ethnocultural & $\begin{array}{l}\text { Protection of Russian speaking population's } \\
\text { rights, Russian language and culture }\end{array}$ \\
\hline $\begin{array}{l}\text { Ogólnokrajowa Zjed- } \\
\text { noczona Rada Szkół } \\
\text { Rosyjskich }\end{array}$ & Ethnocultural & $\begin{array}{l}\text { Protection of Russian schools in Moldova; } \\
\text { protection of Russian speaking population's } \\
\text { rights; protection of Russian language and } \\
\text { culture }\end{array}$ \\
\hline $\begin{array}{l}\text { Stowarzyszenie Rosjan } \\
\text { m. Kamenki }\end{array}$ & Ethnocultural & $\begin{array}{l}\text { Protection of Russian speaking population's } \\
\text { rights, Russian language and culture }\end{array}$ \\
\hline $\begin{array}{l}\text { Stowarzyszenie Rosjan } \\
\text { m. Dniestrowska }\end{array}$ & Ethnocultural & $\begin{array}{l}\text { Protection of Russian speaking population's } \\
\text { rights, Russian language and culture }\end{array}$ \\
\hline
\end{tabular}


Table 2. cont.

\begin{tabular}{|c|c|c|}
\hline Organization & Types & Goals \\
\hline $\begin{array}{l}\text { Stowarzyszenie Rosjan } \\
\text { Republiki Mołdowy }\end{array}$ & Ethnocultural & $\begin{array}{l}\text { Protection of Russian speaking population's } \\
\text { rights, Russian language and culture }\end{array}$ \\
\hline $\begin{array}{l}\text { Rosyjskie Centrum } \\
\text { Intelektualne }\end{array}$ & Ethnocultural & $\begin{array}{l}\text { Development of Russian education; protec- } \\
\text { tion of Russian speaking population's rights; } \\
\text { protection of Russian language }\end{array}$ \\
\hline $\begin{array}{l}\text { Rosyjski Klub Histo- } \\
\text { ryczno-Patriotyczny }\end{array}$ & Ethnocultural & $\begin{array}{l}\text { Popularization of Russian patriotism among } \\
\text { Russian youth; development of Russian } \\
\text { culture }\end{array}$ \\
\hline $\begin{array}{l}\text { Rosyjskie Centrum } \\
\text { Kultury }\end{array}$ & Ethnocultural & $\begin{array}{l}\text { Protection, development and popularization } \\
\text { of Russian culture }\end{array}$ \\
\hline $\begin{array}{l}\text { Stowarzyszenie } \\
\text { Rosyjsko-Słowiańskie } \\
\text { m. Kaguł }\end{array}$ & Ethnocultural & $\begin{array}{l}\text { Protection, development and popularization } \\
\text { of Russian culture; support for "sootečestven- } \\
\text { nikov" }\end{array}$ \\
\hline $\begin{array}{l}\text { Rosyjskie Zjednoczenie } \\
\text { Duchowe }\end{array}$ & Ethnopolitical & $\begin{array}{l}\text { Protection of Russian and Russian speaking } \\
\text { population's rights; unification of Russian } \\
\text { minority organizations; cultural and econom- } \\
\text { ic cooperation between Russia and Moldova }\end{array}$ \\
\hline $\begin{array}{l}\text { Towarzystwo Malarzy } \\
\text { Rosyjskich Mołdawii } \\
\text { "M-ART" }\end{array}$ & Ethnocultural & $\begin{array}{l}\text { Uniting Russian painters in Moldova; pro- } \\
\text { tection of Russian art and Russian artists' } \\
\text { copyrights }\end{array}$ \\
\hline $\begin{array}{l}\text { Centrum Kultury } \\
\text { Rosyjskiej w Mołdowie }\end{array}$ & Ethnocultural & $\begin{array}{l}\text { Protection, development and popularization } \\
\text { of Russian culture; work with Russian and } \\
\text { Russian speaking youth }\end{array}$ \\
\hline \multicolumn{3}{|c|}{ UKRAINE } \\
\hline $\begin{array}{l}\text { Rosyjska Wspólnota } \\
\text { Krymu "Ojczyzna" }\end{array}$ & Ethnocultural & $\begin{array}{l}\text { Development of Russian culture; } \\
\text { Ukrainian-Russian cooperation }\end{array}$ \\
\hline $\begin{array}{l}\text { Ogólnoukraińskie } \\
\text { Towarzystwo Kultury } \\
\text { Rosyjskiej "Ruśs" }\end{array}$ & Ethnocultural & $\begin{array}{l}\text { Educational and scientific activity for the } \\
\text { benefit of Russian language and culture; } \\
\text { protection of Russian minority's rights; scien- } \\
\text { tific cooperation between educational centers } \\
\text { in Ukraine and Russia }\end{array}$ \\
\hline $\begin{array}{l}\text { Rosyjskie Towarzystwo } \\
\text { im. A. Puszkina }\end{array}$ & Ethnocultural & $\begin{array}{l}\text { Development of Russian culture; protection of } \\
\text { Russian population's interests; development } \\
\text { of Ukrainian-Russian cultural cooperation }\end{array}$ \\
\hline $\begin{array}{l}\text { Chersońskie Towarzy- } \\
\text { stwo Inteligencji } \\
\text { Rosyjskiej "Ruśs" }\end{array}$ & Ethnocultural & Promoting Russian culture \\
\hline
\end{tabular}


Table 2. cont.

\begin{tabular}{|c|c|c|}
\hline Organization & Types & Goals \\
\hline $\begin{array}{l}\text { Chmielnickie To- } \\
\text { warzystwo Kultury } \\
\text { Rosyjskiej "Ruśs" }\end{array}$ & Ethnocultural & $\begin{array}{l}\text { Uniting Russian and Russian speaking } \\
\text { population in the central region; protection of } \\
\text { Russian population's interests; contacts with } \\
\text { Russia }\end{array}$ \\
\hline $\begin{array}{l}\text { Krymska Wspólnota } \\
\text { Rosyjskiej Kultury }\end{array}$ & Ethnocultural & $\begin{array}{l}\text { Development of Russian culture in Crimea; } \\
\text { development of Ukrainian-Russian cultural } \\
\text { cooperation }\end{array}$ \\
\hline $\begin{array}{l}\text { Towarzystwo Inteligen- } \\
\text { cji Rosyjskiej "Ruś" }\end{array}$ & Ethnocultural & $\begin{array}{l}\text { Protection of Russian culture; official state } \\
\text { status for Russian language; development of } \\
\text { Ukrainian-Russian cultural cooperation }\end{array}$ \\
\hline $\begin{array}{l}\text { Zakarpackie Towarzy- } \\
\text { stwo Kultury Rosyjskiej } \\
\text { "Rosyjski Dom" }\end{array}$ & Ethnocultural & $\begin{array}{l}\text { Development of Russian culture; scientific } \\
\text { research of Russian ethnic component }\end{array}$ \\
\hline $\begin{array}{l}\text { Krymski Związek } \\
\text { Kozaków }\end{array}$ & Ethnocultural & $\begin{array}{l}\text { Cooperation with Ukrainian orthodox church } \\
\text { of Russian Patriarchate }\end{array}$ \\
\hline $\begin{array}{l}\text { Towarzystwo Kultural- } \\
\text { no-Oświatowe "Rosyj- } \\
\text { skie Zebranie" }\end{array}$ & Ethnocultural & $\begin{array}{l}\text { Development of Russian language; uniting } \\
\text { Russian speaking artists; development of } \\
\text { cultural and economic contacts with Russia }\end{array}$ \\
\hline $\begin{array}{l}\text { Odesskie Miejskie } \\
\text { Ukraińskie Towarzy- } \\
\text { stwo Kultury Rosyjskiej } \\
\text { "Ruś" }\end{array}$ & Ethnocultural & $\begin{array}{l}\text { Protection of Russian culture; official state } \\
\text { status for Russian language }\end{array}$ \\
\hline $\begin{array}{l}\text { Ogólnoukraińskie Naro- } \\
\text { dowe Kulturowo-Oświa- } \\
\text { towe Towarzystwo } \\
\text { "Zebranie Rosyjskie" }\end{array}$ & Ethnocultural & $\begin{array}{l}\text { Official state status for Russian language; } \\
\text { enhancing Russian-Ukrainian cooperation in } \\
\text { the area of culture and science }\end{array}$ \\
\hline $\begin{array}{l}\text { Zaporoskie Miejskie } \\
\text { Towarzystwo Rosyjskiej } \\
\text { Kultury "Ruś" }\end{array}$ & Ethnocultural & $\begin{array}{l}\text { Satisfying cultural and national needs of } \\
\text { Russian minority }\end{array}$ \\
\hline $\begin{array}{l}\text { Charkowskie Miejskie } \\
\text { Społeczno-Patriotyczne } \\
\text { Centrum "Rosjanie" }\end{array}$ & Ethnocultural & $\begin{array}{l}\text { Development and promoting Russian culture, } \\
\text { literature and language; development of cul- } \\
\text { tural and economic contacts with Russia }\end{array}$ \\
\hline $\begin{array}{l}\text { Izmaiłskie Towarzystwo } \\
\text { im. A. Puszkina }\end{array}$ & Ethnocultural & $\begin{array}{l}\text { Promoting and development of Russian } \\
\text { language }\end{array}$ \\
\hline $\begin{array}{l}\text { Rosyjska Wspólnota } \\
\text { Bukowiny }\end{array}$ & Ethnocultural & $\begin{array}{l}\text { Development of Russian language and } \\
\text { culture }\end{array}$ \\
\hline $\begin{array}{l}\text { Rosyjska Wspólnota } \\
\text { Krymu }\end{array}$ & Ethnopolitical & $\begin{array}{l}\text { Uniting population of Russian origin in } \\
\text { Crimea, alliance between Crimea and Russia; } \\
\text { preventing integration of Ukraine and NATO }\end{array}$ \\
\hline $\begin{array}{l}\text { Wspólnota Rosyjska } \\
\text { Obwodu Lwowskiego }\end{array}$ & Ethnocultural & $\begin{array}{l}\text { Protection of Russian population's interests } \\
\text { in western region }\end{array}$ \\
\hline $\begin{array}{l}\text { Wspólnota Rosyjska } \\
\text { Sewastopola }\end{array}$ & Ethnopolitical & $\begin{array}{l}\text { Official state status for Russian language; } \\
\text { localization of the Black Sea Fleet in Crimea; } \\
\text { separation of Crimea from Ukraine }\end{array}$ \\
\hline
\end{tabular}


Table 2. cont.

\begin{tabular}{|c|c|c|}
\hline Organization & Types & Goals \\
\hline $\begin{array}{l}\text { Zwiazek Prawosławnych } \\
\text { Bractw UCP Patriarcha- } \\
\text { tu Moskiewskiego }\end{array}$ & Ethnocultural & $\begin{array}{l}\text { Development of canonic orthodox faith in } \\
\text { Ukrainian territory; development of cultural } \\
\text { contacts between Ukraine and Russia }\end{array}$ \\
\hline $\begin{array}{l}\text { Wspólnota Rosyjska } \\
\text { Obwodu Donieckiego }\end{array}$ & Ethnocultural & $\begin{array}{l}\text { Popularization of Russian culture; economic } \\
\text { and cultural contacts with Russia }\end{array}$ \\
\hline $\begin{array}{l}\text { Wspólnota Rosyjska } \\
\text { Obwodu Iwano-Fran- } \\
\text { kowskiego }\end{array}$ & Ethnocultural & Protection of Russian language and culture \\
\hline $\begin{array}{l}\text { Wspólnota Rosyjska } \\
\text { Obwodu Rowieńskiego }\end{array}$ & Ethnocultural & Popularization of Russian culture \\
\hline $\begin{array}{l}\text { Stowarzyszenie Kultury } \\
\text { i Oświaty } \\
\text { "Dom Rosyjski" }\end{array}$ & Ethnocultural & Development of Russian culture \\
\hline $\begin{array}{l}\text { Towarzystwo Kozaków } \\
\text { Dońskich Obwodu } \\
\text { Eugańskiego }\end{array}$ & Ethnocultural & Popularization of Russian culture \\
\hline $\begin{array}{l}\text { Chersońskie Obwodowe } \\
\text { Ukraińskie Towarzy- } \\
\text { stwo Kultury Rosyjskiej } \\
\text { "Ruś" }\end{array}$ & Ethnocultural & Protection of Russian language and culture \\
\hline $\begin{array}{l}\text { Kongres Rosyjskich } \\
\text { Organizacji Krymu }\end{array}$ & Ethnopolitical & $\begin{array}{l}\text { Protection of Russian interests in Crimea; } \\
\text { double citizenship; uniting of Crimea and } \\
\text { Russia; Ukrainian-Russian cooperation }\end{array}$ \\
\hline $\begin{array}{l}\text { Rosyjskie Narodowo- } \\
\text {-Kulturalne Towarzy- } \\
\text { stwo Obwodu Charkow- } \\
\text { skiego }\end{array}$ & Ethnocultural & $\begin{array}{l}\text { Popularization of Russian language and } \\
\text { culture }\end{array}$ \\
\hline $\begin{array}{l}\text { Wspólnota Rosyjska } \\
\text { Dniepropietrowska }\end{array}$ & Ethnocultural & $\begin{array}{l}\text { Development of Russian national identity; } \\
\text { official state status for Russian language }\end{array}$ \\
\hline $\begin{array}{l}\text { Słowiański Sobór "Ro- } \\
\text { syjska Wspólnota Za- } \\
\text { karpackie Odrodzenie" }\end{array}$ & Ethnocultural & $\begin{array}{l}\text { Protection of Russians' interests and satisfy- } \\
\text { ing their cultural aspirations }\end{array}$ \\
\hline $\begin{array}{l}\text { Stowarzyszeie } \\
\text { Rosyjskich Wspólnot } \\
\text { i Organizacji Obwodu } \\
\text { Lwowskiego }\end{array}$ & Ethnocultural & $\begin{array}{l}\text { Protection of cultural and educational inter- } \\
\text { ests of Russian population }\end{array}$ \\
\hline $\begin{array}{l}\text { Centrum Kultury } \\
\text { Rosyjskiej "Cyrylica" }\end{array}$ & Ethnocultural & Development of Russian national identity \\
\hline $\begin{array}{l}\text { Konfederacja Rosyjskich } \\
\text { Wspólnot i Organizacji } \\
\text { Zachodnich Obwodów } \\
\text { Ukrainy }\end{array}$ & Ethnocultural & $\begin{array}{l}\text { Consolidation of Russian organizations in } \\
\text { western Ukraine; official state status for } \\
\text { Russian language; promoting Ukrainian-Rus- } \\
\text { sian cooperation in the area of economy and } \\
\text { culture }\end{array}$ \\
\hline $\begin{array}{l}\text { Wspólnota Rosyjska } \\
\text { m. Kijów }\end{array}$ & Ethnocultural & Promoting Russian tradition and culture \\
\hline
\end{tabular}


Table 2. cont.

\begin{tabular}{|c|c|c|}
\hline Organization & Types & Goals \\
\hline $\begin{array}{l}\text { Dniepropietrowska } \\
\text { Organizacja Obwodowa } \\
\text { "Ruśs" }\end{array}$ & Ethnocultural & $\begin{array}{l}\text { Protection of cultural and educational inter- } \\
\text { ests of Russian population }\end{array}$ \\
\hline $\begin{array}{l}\text { Dniepropietrowska } \\
\text { Obwodowa Organizacja } \\
\text { Społeczna "Ruś" }\end{array}$ & Ethnocultural & $\begin{array}{l}\text { Protection of Russian and Russian speaking } \\
\text { population's interests; development of } \\
\text { Ukrainian-Russian cooperation in the area of } \\
\text { culture }\end{array}$ \\
\hline $\begin{array}{l}\text { Rada Rosyjskich } \\
\text { i Ruskich Wspólnot } \\
\text { Krymu }\end{array}$ & Ethnocultural & $\begin{array}{l}\text { Consolidation of Russian speaking population } \\
\text { of Crimea; protection of Russian's rights; } \\
\text { development of political and economic } \\
\text { Russian-Ukrainian contacts }\end{array}$ \\
\hline $\begin{array}{l}\text { Rosyjskie Centrum } \\
\text { Młodzieżowe Krymu }\end{array}$ & Ethnocultural & $\begin{array}{l}\text { Promotion of Russian culture among the } \\
\text { youth in the peninsula; cultural contacts with } \\
\text { Russian youth }\end{array}$ \\
\hline $\begin{array}{l}\text { Połtawska Obwodowa } \\
\text { Organizacja Wspólnota } \\
\text { Rosyjska Obwodu } \\
\text { Połtawskiego }\end{array}$ & Ethnocultural & $\begin{array}{l}\text { Protection of Russian and Russian speaking } \\
\text { population's cultural and educational } \\
\text { interests }\end{array}$ \\
\hline $\begin{array}{l}\text { Wspólnota Rosyjska } \\
\text { m. Czernihów "Ruś” }\end{array}$ & Ethnocultural & $\begin{array}{l}\text { Protection of cultural and language rights of } \\
\text { the inhabitants of the city }\end{array}$ \\
\hline $\begin{array}{l}\text { Organizacja "Zjednocze- } \\
\text { nie Poetów Rosyjskich } \\
\text { i Rosyjskojęzycz. Obwo- } \\
\text { du Winnickiego" }\end{array}$ & Ethnocultural & $\begin{array}{l}\text { Popularization of Russian and culture and } \\
\text { literature }\end{array}$ \\
\hline Rosyjska Rada Ukrainy & Ethnocultural & $\begin{array}{l}\text { Protection of Russian's interests; } \\
\text { Ukrainian-Russian cooperation in the area of } \\
\text { science and culture }\end{array}$ \\
\hline $\begin{array}{l}\text { Wspólnota Rosyjska } \\
\text { Ukrainy }\end{array}$ & Ethnocultural & $\begin{array}{l}\text { Protection of Russian's cultural rights; official } \\
\text { state status for Russian language; alliance of } \\
\text { Ukraine, Belarus and Russia }\end{array}$ \\
\hline Rosyjski Ruch Ukrainy & Ethnopolitical & $\begin{array}{l}\text { Building of multi ethnic civic society; official } \\
\text { state status for Russian language; integra- } \\
\text { tion of Ukraine, Belarus and Russia; protest } \\
\text { against NATO }\end{array}$ \\
\hline $\begin{array}{l}\text { Narodowe Kulturalne } \\
\text { Centrum "Odrodzenie } \\
\text { Rosyjskie" }\end{array}$ & Ethnocultural & $\begin{array}{l}\text { Popularization of Russian and culture and } \\
\text { literature; Ukrainian-Russian cooperation in } \\
\text { the area of culture }\end{array}$ \\
\hline $\begin{array}{l}\text { Wspólnota Rosyjska } \\
\text { m. Połtawa }\end{array}$ & Ethnocultural & Observing Russian rights in Poltava \\
\hline $\begin{array}{l}\text { Wspólnota Rosyjsko- } \\
\text { języczna "Słowianie" }\end{array}$ & Ethnocultural & Development of Russian language \\
\hline $\begin{array}{l}\text { Ukraińskie Stowa- } \\
\text { rzyszenie Nauczycieli } \\
\text { Języka i Literatury } \\
\text { Rosyjskiej }\end{array}$ & Ethnocultural & $\begin{array}{l}\text { Popularization, protection and development } \\
\text { of Russian language and culture, establish- } \\
\text { ment of world scientific center of Russian } \\
\text { language }\end{array}$ \\
\hline
\end{tabular}


Table 2. cont.

\begin{tabular}{|c|c|c|}
\hline Organization & Types & Goals \\
\hline $\begin{array}{l}\text { Charkowska Organi- } \\
\text { zacja Obwodowa "Za } \\
\text { Równość Kulturowo- } \\
\text {-Językowa" }\end{array}$ & Ethnocultural & $\begin{array}{l}\text { Official state status for Russian language; } \\
\text { intensification of multidimensional coopera- } \\
\text { tion with Russia and CIS countries }\end{array}$ \\
\hline $\begin{array}{l}\text { Mikołajewska } \\
\text { Obwodowa Organizacja } \\
\text { "Rosyjska Wspólnota } \\
\text { Narodowa Rusicz" }\end{array}$ & Ethnocultural & $\begin{array}{l}\text { Popularization of Russian literature and } \\
\text { culture; Ukrainian-Russian cooperation in } \\
\text { the area of culture }\end{array}$ \\
\hline $\begin{array}{l}\text { Odesska Regionalna } \\
\text { Organizacja Społeczna } \\
\text { "Jedna Ojczyzna" }\end{array}$ & Ethnocultural & $\begin{array}{l}\text { Unification of orthodox church in the spirit } \\
\text { of Moscow Patriarchate; federalization of } \\
\text { Ukraine; development of Ukrainian-Russian } \\
\text { relations }\end{array}$ \\
\hline $\begin{array}{l}\text { Wspólnota Rosyjska } \\
\text { Połtawszczyzny }\end{array}$ & Ethnocultural & $\begin{array}{l}\text { Free use of Russian language; protection of } \\
\text { Russian population's cultural rights }\end{array}$ \\
\hline $\begin{array}{l}\text { Związek Prawosławnych } \\
\text { Obywateli Ukrainy }\end{array}$ & Ethnocultural & Protection of Russian church in Ukraine \\
\hline $\begin{array}{l}\text { Kirowogradzki Fundusz } \\
\text { im. N. N. Rajewskiego }\end{array}$ & Ethnocultural & $\begin{array}{l}\text { Official state status for Russian language; } \\
\text { development of Russian culture }\end{array}$ \\
\hline $\begin{array}{l}\text { Spadkobiercy Bohdana } \\
\text { Chmielnickiego }\end{array}$ & Ethnopolitical & $\begin{array}{l}\text { Official state status for Russian language; } \\
\text { expanding of Crimean autonomy; protest } \\
\text { against Ukrainian membership in NATO; } \\
\text { economic and cultural integration of former } \\
\text { Soviet republics }\end{array}$ \\
\hline $\begin{array}{l}\text { Prawosławne Bractwo } \\
\text { Św. Księcia A. Newskie- } \\
\text { go Rosyjskiego Ruchu } \\
\text { Ukrainy }\end{array}$ & Ethnocultural & $\begin{array}{l}\text { Development of Russian culture and tradi- } \\
\text { tions }\end{array}$ \\
\hline $\begin{array}{l}\text { Rosyjsko-Ukraińskie } \\
\text { Centrum Kulturowo- } \\
\text {-Oświatowe "Rodacy" } \\
\text { m. Winnica }\end{array}$ & Ethnocultural & $\begin{array}{l}\text { Communicating in Russian language in } \\
\text { Ukrainian schools; official state status for } \\
\text { Russian language }\end{array}$ \\
\hline $\begin{array}{l}\text { SRUB Sojusz Rosji, } \\
\text { Ukrainy i Białorusi }\end{array}$ & Ethnopolitical & $\begin{array}{l}\text { Protection of Russian, Belarusian, Ukrainian } \\
\text { population's rights; development of } \\
\text { Ukrainian-Russian-Belarusian relations }\end{array}$ \\
\hline $\begin{array}{l}\text { Międzynarodowa Orga- } \\
\text { nizacja "Wierni Kozacy" }\end{array}$ & Ethnocultural & $\begin{array}{l}\text { Official state status for Russian language; } \\
\text { protection of Russian culture }\end{array}$ \\
\hline $\begin{array}{l}\text { Narodowo-Kulturowy } \\
\text { Twórczy Zwiazek Rosyjs- } \\
\text { kich Dziennikarzy } \\
\text { i Literatów }\end{array}$ & Ethnocultural & $\begin{array}{l}\text { Development of Russian language; observing } \\
\text { Russian minority's rights; Ukrainian-Russian } \\
\text { cooperation in the area of culture }\end{array}$ \\
\hline $\begin{array}{l}\text { Ukraińska Akademia } \\
\text { Rusycystyki }\end{array}$ & Ethnocultural & $\begin{array}{l}\text { Development of Russian language studies; } \\
\text { preventing the reduction of Russian speaking } \\
\text { educational centers }\end{array}$ \\
\hline
\end{tabular}


Table 2. cont.

\begin{tabular}{|c|c|c|}
\hline Organization & Types & Goals \\
\hline $\begin{array}{l}\text { Rosyjskie Centrum } \\
\text { Kulturalne Obwodu } \\
\text { Rowieńskiego }\end{array}$ & Ethnocultural & $\begin{array}{l}\text { Official state status for Russian language; } \\
\text { protection of Russian minority's rights }\end{array}$ \\
\hline $\begin{array}{l}\text { Związek Narodu Rosyj- } \\
\text { skiego }\end{array}$ & Ethnocultural & $\begin{array}{l}\text { Acknowledgment of Russian minority as } \\
\text { state-creating nation; Ukrainian-Russian } \\
\text { cooperation }\end{array}$ \\
\hline $\begin{array}{l}\text { Obwodowa Odesska } \\
\text { Organizacja "Rosyjski } \\
\text { Zwiazek Nadczarno- } \\
\text { morza }\end{array}$ & Ethnocultural & $\begin{array}{l}\text { Communicating in Russian language in } \\
\text { Ukrainian schools; preventing the discrimi- } \\
\text { nation of Russian population }\end{array}$ \\
\hline $\begin{array}{l}\text { Ogólnoukraińska } \\
\text { Organizacja Społeczna } \\
\text { Szkoła Rosyjska }\end{array}$ & Ethnocultural & $\begin{array}{l}\text { Development of Russian literature and } \\
\text { culture; official state status for Russian } \\
\text { language; multidimensional contacts between } \\
\text { Russia and Ukraine }\end{array}$ \\
\hline $\begin{array}{l}\text { Fundusz Wsparcia } \\
\text { Kultury Rosyjskiej na } \\
\text { Ukrainie }\end{array}$ & Ethnocultural & $\begin{array}{l}\text { Communicating in Russian language in } \\
\text { Ukrainian schools; multidimensional contacts } \\
\text { between Russia and Ukraine }\end{array}$ \\
\hline $\begin{array}{l}\text { Ogólnoukraińska Zjed- } \\
\text { noczona Organizacja } \\
\text { "Wspólnota Rosyjska" }\end{array}$ & Ethnocultural & $\begin{array}{l}\text { Preventing the discrimination of Russian } \\
\text { population }\end{array}$ \\
\hline $\begin{array}{l}\text { Ogólnoukraińska } \\
\text { Organizacja Ochrony } \\
\text { Praw "Rosyjskojęzyczna } \\
\text { Ukraina" }\end{array}$ & Ethnocultural & $\begin{array}{l}\text { Protection of Russian speaking population's } \\
\text { rights; official state status for Russian lan- } \\
\text { guage; Ukrainian-Russian cooperation in the } \\
\text { area of economy and culture }\end{array}$ \\
\hline $\begin{array}{l}\text { Charkowskie } \\
\text { Towarzystwo } \\
\text { Regionalne "Ruś" }\end{array}$ & Ethnocultural & promoting Russian literature and poetry \\
\hline $\begin{array}{l}\text { Organizacja "Rosyjski } \\
\text { Zjazd Narodowy" }\end{array}$ & Ethnocultural & $\begin{array}{l}\text { Communicating in Russian language in } \\
\text { Ukrainian schools; preventing the discrimi- } \\
\text { nation of Russian population }\end{array}$ \\
\hline $\begin{array}{l}\text { Wspólnota Rosyjska } \\
\text { m. Charków }\end{array}$ & Ethnocultural & $\begin{array}{l}\text { Preventing the discrimination of Russian } \\
\text { population }\end{array}$ \\
\hline $\begin{array}{l}\text { Rosyjska Wspólnota } \\
\text { Narodowa "Rusicz" }\end{array}$ & Ethnocultural & $\begin{array}{l}\text { Promoting Russian culture, literature and } \\
\text { poetry }\end{array}$ \\
\hline $\begin{array}{l}\text { Rosyjskie Ziemiaństwo } \\
\text { m. Teodozji }\end{array}$ & Ethnocultural & Promoting Russian culture \\
\hline $\begin{array}{l}\text { Rosyjski Ruch Młodzie- } \\
\text { żowy Ukrainy }\end{array}$ & Ethnocultural & $\begin{array}{l}\text { Promoting Russian culture; Ukrainian-Rus- } \\
\text { sian cooperation in the area of science and } \\
\text { culture }\end{array}$ \\
\hline $\begin{array}{l}\text { Rosyjski Związek } \\
\text { Narodowy }\end{array}$ & Ethnocultural & $\begin{array}{l}\text { Preventing the discrimination of Russian } \\
\text { population }\end{array}$ \\
\hline
\end{tabular}

Source: author's own elaboration based on: Obŝestvennyje..., 2017; Organizacii Sootečestvennikov za rubežom. Belorus', 2017; Organizacii Sootečestvennikov za rubežom. Moldoviâ, 2017; Russkie..., 2017. 
Table 3. Selected non-governmental organizations representing the interests of the Russian minority in the countries of Eastern Europe in the years 1991-2018

\begin{tabular}{|c|c|c|c|c|}
\hline $\begin{array}{l}\text { Organization / } \\
\text { Year of establishment }\end{array}$ & $\begin{array}{l}\text { No. of ind. } \\
\text { / legal } \\
\text { members }\end{array}$ & Branches & $\begin{array}{l}\text { Publishing } \\
\text { activity } \\
\text { (periodicals) }\end{array}$ & $\begin{array}{l}\text { Territorial } \\
\text { Reach }\end{array}$ \\
\hline \multicolumn{5}{|c|}{ BELARUS } \\
\hline $\begin{array}{l}\text { Zjednoczenie Nauczycieli Języka } \\
\text { i Literatury Rosyjskiej (2003) }\end{array}$ & $120 /-$ & 5 & $\begin{array}{l}\text { Didactic aids } \\
\text { for teachers }\end{array}$ & Nation-wide \\
\hline $\begin{array}{l}\text { Białoruskie Powszechne Stowa- } \\
\text { rzyszenie "Ruś" (2000) }\end{array}$ & $200 /-$ & 8 & - & Nation-wide \\
\hline $\begin{array}{l}\text { Witebskie Stowarzyszenie } \\
\text { Powszechne "Rosyjski Dom" } \\
(2002)\end{array}$ & - & - & "Istoki" & Regional \\
\hline $\begin{array}{l}\text { Koordynacyjna Rada Przewodni- } \\
\text { czacych Organizacji Rosyjskich } \\
\text { Rodaków (2007) }\end{array}$ & $11 /-$ & - & - & Nation-wide \\
\hline $\begin{array}{l}\text { Mińskie Towarzystwo Kultury } \\
\text { Rosyjskiej "Ruś" (1992) }\end{array}$ & $1100 /-$ & - & $\begin{array}{l}\text { Informational } \\
\text { brochures }\end{array}$ & Regional \\
\hline $\begin{array}{l}\text { Powszechne Stowarzyszenie } \\
\text { Rosyjski Ośrodek Kultury "Ruś" } \\
\text { (1994) }\end{array}$ & $28 /-$ & - & - & Nation-wide \\
\hline $\begin{array}{l}\text { Republikańskie Stowarzyszenie } \\
\text { Powszechne "Białoruski Zwiazek } \\
\text { Literatów" "Połacka Gałąź" (1994) }\end{array}$ & - & 14 & - & Nation-wide \\
\hline $\begin{array}{l}\text { Republikańskie Publiczne Stowa- } \\
\text { rzyszenie "Rosyjska Wspólnota" } \\
\text { (1994) }\end{array}$ & $500 /-$ & 6 & $\begin{array}{l}\text { School course- } \\
\text { books }\end{array}$ & Nation-wide \\
\hline $\begin{array}{l}\text { Białoruskie Stowarzyszenie } \\
\text { Powszechne "Ruś" (2000) }\end{array}$ & $200 /-$ & 6 & - & Nation-wide \\
\hline \multicolumn{5}{|c|}{ MOLDOVA } \\
\hline $\begin{array}{l}\text { Zwiazek Przedsiębiorców Rosyj- } \\
\text { skich Republiki Mołdowy (1998) }\end{array}$ & - & - & - & Nation-wide \\
\hline "Nasze Pokolenie" (2009) & 98 & - & $\begin{array}{l}\text { "Naše } \\
\text { Pokolenie" }\end{array}$ & Nation-wide \\
\hline $\begin{array}{l}\text { Kiszyniowskie Stowarzyszenie } \\
\text { Rosjan (1996) }\end{array}$ & - & - & $\begin{array}{l}\text { "Naša } \\
\text { Obşčina" }\end{array}$ & Regional \\
\hline $\begin{array}{l}\text { Kongres Organizacji Rosyjskich } \\
\text { Mołdowy (1997) }\end{array}$ & $-/ 28$ & yes & - & Nation-wide \\
\hline $\begin{array}{l}\text { Rada Koordynacyjna Rosyjskich } \\
\text { Rodaków (2000) }\end{array}$ & - & - & - & Nation-wide \\
\hline $\begin{array}{l}\text { Liga Młodzieży Rosyjskiej Repub- } \\
\text { liki Mołdowy (2001) }\end{array}$ & - & - & - & Nation-wide \\
\hline
\end{tabular}


Table 3. cont.

\begin{tabular}{|c|c|c|c|c|}
\hline $\begin{array}{c}\text { Organization / } \\
\text { Year of establishment }\end{array}$ & $\begin{array}{l}\text { No. of ind. } \\
\text { / legal } \\
\text { members }\end{array}$ & Branches & $\begin{array}{l}\text { Publishing } \\
\text { activity } \\
\text { (periodicals) }\end{array}$ & $\begin{array}{l}\text { Territorial } \\
\text { Reach }\end{array}$ \\
\hline $\begin{array}{l}\text { Zjednoczona Organizacja "Ruś" } \\
(2003)\end{array}$ & $321 /-$ & - & "Rusin" & Nation-wide \\
\hline $\begin{array}{l}\text { Stowarzyszenie Rosjan m. Lipka- } \\
\text { ny (2002) }\end{array}$ & - & - & - & Regional \\
\hline $\begin{array}{l}\text { Stowarzyszenie Rosjan Gagauzii } \\
(2000)\end{array}$ & - & - & - & Regional \\
\hline $\begin{array}{l}\text { Stowarzyszenie Rosjan Regionu } \\
\text { Drokijewskigo (2005) }\end{array}$ & - & - & - & Regional \\
\hline $\begin{array}{l}\text { Stowarzyszenie Rosjan Regionu } \\
\text { Edineckiego (1999) }\end{array}$ & - & - & - & Regional \\
\hline $\begin{array}{l}\text { Stowarzyszenie Rosjan Regionu } \\
\text { Rezinskiego (2000) }\end{array}$ & - & - & - & Regional \\
\hline $\begin{array}{l}\text { Stowarzyszenie Rosjan Regionu } \\
\text { Ryszkanskiego (2007) }\end{array}$ & - & - & - & Regional \\
\hline $\begin{array}{l}\text { Stowarzyszenie Rosjan Regionu } \\
\text { Straszenskiego (2006) }\end{array}$ & - & - & - & Regional \\
\hline $\begin{array}{l}\text { Stowarzyszenie Rosjan Regionu } \\
\text { Ungenskiego (2003) }\end{array}$ & - & - & - & Regional \\
\hline $\begin{array}{l}\text { Stowarzyszenie Rosjan Regionu } \\
\text { Falesztskiego }\end{array}$ & - & - & - & Regional \\
\hline $\begin{array}{l}\text { Stowarzyszenie Rosjan Regionu } \\
\text { Chynczesztskiego (2001) }\end{array}$ & - & - & - & Regional \\
\hline $\begin{array}{l}\text { Stowarzyszenie Rosjan Republiki } \\
\text { Mołdowy (1993) }\end{array}$ & - & 43 & - & Nation-wide \\
\hline $\begin{array}{l}\text { Rosyjskie Centrum Intelektualne } \\
(2003)\end{array}$ & - & - & "Russkaâ & Nation-wide \\
\hline $\begin{array}{l}\text { Rosyjski Klub Historyczno- } \\
\text {-Patriotyczny (2009) }\end{array}$ & - & - & - & Nation-wide \\
\hline $\begin{array}{l}\text { Stowarzyszenie Rosyjsko- } \\
\text {-Słowiańskie m. Kaguł (1995) }\end{array}$ & - & - & - & Regional \\
\hline $\begin{array}{l}\text { Towarzystwo Malarzy Rosyjskich } \\
\text { Mołdawii "M-ART" (2004) }\end{array}$ & - & - & - & Nation-wide \\
\hline $\begin{array}{l}\text { Centrum Kultury Rosyjskiej } \\
\text { w Mołdowie (1989) }\end{array}$ & $72 / 7$ & - & - & Nation-wide \\
\hline \multicolumn{5}{|c|}{ UKRAINE } \\
\hline $\begin{array}{l}\text { Rosyjska Wspólnota Krymu } \\
\text { "Ojczyzna” (1987) }\end{array}$ & $700 /-$ & - & - & Regional \\
\hline
\end{tabular}


Table 3. cont.

\begin{tabular}{|c|c|c|c|c|}
\hline $\begin{array}{c}\text { Organization / } \\
\text { Year of establishment }\end{array}$ & $\begin{array}{l}\text { No. of ind. } \\
\text { / legal } \\
\text { members }\end{array}$ & Branches & $\begin{array}{l}\text { Publishing } \\
\text { activity } \\
\text { (periodicals) }\end{array}$ & $\begin{array}{l}\text { Territorial } \\
\text { Reach }\end{array}$ \\
\hline $\begin{array}{l}\text { Narodowo-Kulturalno-Oświece- } \\
\text { niowe Zjednoczenie "Rosyjskie } \\
\text { Zgromadzenie" (1990) }\end{array}$ & - & - & - & Nation-wide \\
\hline $\begin{array}{l}\text { Ogólnoukraińskie Towarzystwo } \\
\text { Rosyjskiej Kultury “Ruś”(1990) }\end{array}$ & $18,000 /-$ & 23 & - & Nation-wide \\
\hline $\begin{array}{l}\text { Rosyjskie Towarzystwo im. } \\
\text { A. Puszkina (1990) }\end{array}$ & $400 /-$ & 2 & "Sumienie" & Regional \\
\hline $\begin{array}{l}\text { Chersońskie Towarzystwo Rosyj- } \\
\text { skiej Inteligencji "Ruś" (1991) }\end{array}$ & - & - & - & Regional \\
\hline $\begin{array}{l}\text { Chmielnickie Towarzystwo Rosyj- } \\
\text { skiej Kultury "Ruś" (1991) }\end{array}$ & $65 /-$ & 1 & - & Regional \\
\hline $\begin{array}{l}\text { Krymska Wspólnota Kultury } \\
\text { Rosyjskie (1991) }\end{array}$ & - & - & - & Regional \\
\hline $\begin{array}{l}\text { Towarzystwo Inteligencji Rosyj- } \\
\text { skiej "Ruś" (1991) }\end{array}$ & $63 /-$ & 0 & - & Regional \\
\hline $\begin{array}{l}\text { Zakarpackie Towarzystwo Rosyj- } \\
\text { skiej Kultury "Rosyjski Dom" } \\
\text { (1991) }\end{array}$ & - & - & - & Regional \\
\hline Krymski Związek Kozaków (1992) & $800 /-$ & 20 & - & Regional \\
\hline $\begin{array}{l}\text { Kulturalno-Oświatowe Towarzy- } \\
\text { stwo "Rosyjskie Zebranie" (1992) }\end{array}$ & $300 /-$ & - & - & Regional \\
\hline $\begin{array}{l}\text { Odesskie Miejskie Ukraińskie } \\
\text { Towarzystwo Kultury Rosyjskiej } \\
\text { "Ruś" (1992) }\end{array}$ & $100 /-$ & - & - & Regional \\
\hline $\begin{array}{l}\text { Ogólnoukraińskie Narodowe Kul- } \\
\text { turowo-Oświatowe Towarzystwo } \\
\text { "Rosyjskie Zebranie" (1992) }\end{array}$ & - & - & $\begin{array}{l}\text { "Rosyjskie } \\
\text { Zebranie" }\end{array}$ & Nation-wide \\
\hline $\begin{array}{l}\text { Zaporożskie Miejskie Towarzystwo } \\
\text { Rosyjskiej Kultury “Ruś” (1992) }\end{array}$ & $150 /-$ & - & - & Regional \\
\hline $\begin{array}{l}\text { Charkowskie Miejskie Społeczno- } \\
\text {-Patriotyczne Centrum } \\
\text { "Rosjanie" (1993) }\end{array}$ & - & - & - & Regional \\
\hline $\begin{array}{l}\text { Izmaiłskie Towarzystwo } \\
\text { im. A. Puszkina (1993) }\end{array}$ & - & - & - & Regional \\
\hline $\begin{array}{l}\text { Rosyjska Wspólnota Bukowiny } \\
\text { (1993) }\end{array}$ & - & - & - & Regional \\
\hline Rosyjska Wspólnota Krymu (1993) & $15,000 /-$ & 30 & $\begin{array}{l}\text { "Rosyjski } \\
\text { Świat" }\end{array}$ & Regional \\
\hline
\end{tabular}


Table 3. cont.

\begin{tabular}{|c|c|c|c|c|}
\hline $\begin{array}{l}\text { Organization / } \\
\text { Year of establishment }\end{array}$ & $\begin{array}{l}\text { No. of ind. } \\
\text { / legal } \\
\text { members }\end{array}$ & Branches & $\begin{array}{l}\text { Publishing } \\
\text { activity } \\
\text { (periodicals) }\end{array}$ & $\begin{array}{l}\text { Territorial } \\
\text { Reach }\end{array}$ \\
\hline $\begin{array}{l}\text { Rosyjska Wspólnota Obwodu } \\
\text { Lwowskiego (1993) }\end{array}$ & $1000 /-$ & - & $\begin{array}{l}\text { "Dziennik } \\
\text { Rosyjski" }\end{array}$ & Regional \\
\hline $\begin{array}{l}\text { Rosyjska Wspólnota Sewastopola } \\
\text { (1993) }\end{array}$ & $1200 /-$ & - & - & Regional \\
\hline $\begin{array}{l}\text { Zwiazek Prawosławnych Bractw } \\
\text { Ukraińskiej Cerkwi Prawosławnej } \\
\text { Patriarchatu Moskiewskiego } \\
\text { (1993) }\end{array}$ & $5,000 /-$ & - & - & Nation-wide \\
\hline $\begin{array}{l}\text { Rosyjska Wspólnota Obwodu } \\
\text { Donieckiego (1994) }\end{array}$ & $500 /-$ & 3 & - & Regional \\
\hline $\begin{array}{l}\text { Rosyjska Wspólnota Obwodu } \\
\text { Iwan-Frankowskiego (1994) }\end{array}$ & - & 3 & - & Regional \\
\hline $\begin{array}{l}\text { Rosyjska Wspólnota Obwodu } \\
\text { Rowieńskiego (1994) }\end{array}$ & $350 /-$ & - & - & Regional \\
\hline $\begin{array}{l}\text { Stow. Kultury i Oświaty "Rosyjski } \\
\text { Dom" (1994) }\end{array}$ & $300 /-$ & - & - & Regional \\
\hline $\begin{array}{l}\text { Towarzystwo Kozaków Dońskich } \\
\text { Obwodu Ługańskiego (1994) }\end{array}$ & - & - & - & Regional \\
\hline $\begin{array}{l}\text { Chersońskie Obwodowe Ukraiń- } \\
\text { skie Towarzystwo Kultury Rosyj- } \\
\text { skiej "Ruś" (1995) }\end{array}$ & $500 /-$ & - & - & Regional \\
\hline $\begin{array}{l}\text { Kongres Rosyjskich Organizacji } \\
\text { Krymu (1995) }\end{array}$ & $500 / 15$ & - & $\begin{array}{l}\text { „Rosyjski } \\
\text { Krym" }\end{array}$ & Regional \\
\hline $\begin{array}{l}\text { Rosyjskie Narodowo-Kulturalne } \\
\text { Towarzystwo Obwodu Charkow- } \\
\text { skiego (1995) }\end{array}$ & - & - & - & Regional \\
\hline $\begin{array}{l}\text { Rosyjska Wspólnota Dniepropie- } \\
\text { trowska (1995) }\end{array}$ & $65 /-$ & - & $\begin{array}{l}\text { „Rosyjskie } \\
\text { Słowo" }\end{array}$ & Regional \\
\hline $\begin{array}{l}\text { Słowiański Sobór "Rosyjska } \\
\text { Wspólnota Zakarpackie Odrodze- } \\
\text { nie" (1995) }\end{array}$ & $25 /-$ & 3 & - & Regional \\
\hline $\begin{array}{l}\text { Stowarzyszenie Rosyjskich } \\
\text { Wspólnot i Organizacji Obwodu } \\
\text { Lwowskiego (1995) }\end{array}$ & - & - & - & Regional \\
\hline $\begin{array}{l}\text { Centrum Kultury Rosyjskiej } \\
\text { "Cyrylica” (1996) }\end{array}$ & $80 / 5$ & - & - & Regional \\
\hline $\begin{array}{l}\text { Konfederacja Rosyjskich Wspólnot } \\
\text { i Organizacji Zachodnich } \\
\text { Obwodów Ukrainy (1996) }\end{array}$ & - & - & $\begin{array}{l}\text { "Dzień za } \\
\text { Dniem" }\end{array}$ & Regional \\
\hline
\end{tabular}


Table 3. cont.

\begin{tabular}{|c|c|c|c|c|}
\hline $\begin{array}{l}\text { Organization / } \\
\text { Year of establishment }\end{array}$ & $\begin{array}{l}\text { No. of ind. } \\
\text { / legal } \\
\text { members }\end{array}$ & Branches & $\begin{array}{c}\text { Publishing } \\
\text { activity } \\
\text { (periodicals) }\end{array}$ & $\begin{array}{l}\text { Territorial } \\
\text { Reach }\end{array}$ \\
\hline $\begin{array}{l}\text { Rosyjska Wspólnota m. Kijów } \\
\text { (1996) }\end{array}$ & $900 /-$ & 13 & - & Regional \\
\hline $\begin{array}{l}\text { Dniepropietrowska Obwodowa } \\
\text { Organizacja "Ruś" (1997) }\end{array}$ & $830 / 7$ & 5 & - & Regional \\
\hline $\begin{array}{l}\text { Dniepropietrowska Obwodowa } \\
\text { Społeczna Organizacja "Ruś" } \\
\text { (1997) }\end{array}$ & $480 /-$ & - & - & Regional \\
\hline $\begin{array}{l}\text { Rada Rosyjskich i Ruskich Wspól- } \\
\text { not Krymu (1997) }\end{array}$ & $7165 / 6$ & 16 & - & Regional \\
\hline $\begin{array}{l}\text { Rosyjskie Młodzieżowe Centrum } \\
\text { Krymu (1997) }\end{array}$ & $1000 /-$ & 30 & $\begin{array}{l}\text { "Moskiewska } \\
\text { Ulica" }\end{array}$ & Regional \\
\hline $\begin{array}{l}\text { Połtawska Obwodowa Organizacja } \\
\text { "Rosyjska Wspólnota Obwodu } \\
\text { Połtawskiego" (1998) }\end{array}$ & - & 3 & - & Regional \\
\hline $\begin{array}{l}\text { Rosyjska Wspólnota m. Czernigow } \\
\text { "Ruś" (1998) }\end{array}$ & $300 /-$ & - & - & Regional \\
\hline $\begin{array}{l}\text { Organizacja "Zjednoczenie Rosyj- } \\
\text { skich i Rosyjskojęzycznych Poetów } \\
\text { Obwodu Winnickiego" (1999) }\end{array}$ & $120 / 4$ & 6 & $\begin{array}{l}\text { "Pole Litera- } \\
\text { tury" }\end{array}$ & Regional \\
\hline Rosyjska Rada Ukrainy (1999) & - & - & - & Nation-wide \\
\hline $\begin{array}{l}\text { Rosyjska Wspólnota Ukrainy } \\
\text { (1999) }\end{array}$ & $8,000 / 5$ & - & - & Nation-wide \\
\hline Rosyjski Ruch Ukrainy (1999) & $46,000 /-$ & 26 & $\begin{array}{l}\text { "Rosyjski Ruch } \\
\text { Ukrainy" }\end{array}$ & Nation-wide \\
\hline $\begin{array}{l}\text { Narodowe Kulturalne Centrum } \\
\text { "Rosyjskie Odrodzenie" (2000) }\end{array}$ & $2436 / 3$ & 7 & - & Regional \\
\hline $\begin{array}{l}\text { Rosyjska Wspólnota m. Połtawa } \\
(2000)\end{array}$ & - & - & - & Regional \\
\hline $\begin{array}{l}\text { Rosyjskkojęzyczna Wspólnota } \\
\text { Słowianie (2000) }\end{array}$ & - & - & - & Regional \\
\hline $\begin{array}{l}\text { Ukraińskie Stowarzyszenie Na- } \\
\text { uczycieli Języka Rosyjskiego } \\
\text { i Literatury (2000) }\end{array}$ & $50 / 48$ & - & "Rusycystyka" & Nation-wide \\
\hline $\begin{array}{l}\text { Charkowska Obwodowa Orga- } \\
\text { nizacja "Za Równość Kulturowo- } \\
\text {-Językową" (2000) }\end{array}$ & $300 /-$ & - & - & Regional \\
\hline $\begin{array}{l}\text { Mikołajewska Obwodowa } \\
\text { Organizacja "Rosyjska Narodowa } \\
\text { Wspólnota Rusicz" (2001) }\end{array}$ & $309 / 3$ & - & - & Regional \\
\hline
\end{tabular}


Table 3. cont.

\begin{tabular}{|c|c|c|c|c|}
\hline $\begin{array}{c}\text { Organization / } \\
\text { Year of establishment }\end{array}$ & $\begin{array}{l}\text { No. of ind. } \\
\text { / legal } \\
\text { members }\end{array}$ & Branches & $\begin{array}{l}\text { Publishing } \\
\text { activity } \\
\text { (periodicals) }\end{array}$ & $\begin{array}{l}\text { Territorial } \\
\text { Reach }\end{array}$ \\
\hline $\begin{array}{l}\text { Odesska Regionalna Organizacja } \\
\text { Społeczna “Jedna Ojczyzna” (2001) }\end{array}$ & $1300 /-$ & 5 & $\begin{array}{l}\text { "Prawosławny } \\
\text { Telegraf" }\end{array}$ & Regional \\
\hline $\begin{array}{l}\text { Rosyjska Wspólnota Połtawszczyz- } \\
\text { ny (2001) }\end{array}$ & - & - & - & Regional \\
\hline $\begin{array}{l}\text { Związek Prawosławnych } \\
\text { Obywateli Ukrainy (2001) }\end{array}$ & - & - & - & Regional \\
\hline $\begin{array}{l}\text { Kirowogradzki Fundusz im. N.N. } \\
\text { Rajewskiego (2002) }\end{array}$ & $200 /-$ & 5 & - & Regional \\
\hline $\begin{array}{l}\text { Spadkobiercy Bohdana Chmielni- } \\
\text { ckiego (2002) }\end{array}$ & - & - & - & Nation-wide \\
\hline $\begin{array}{l}\text { Prawosławne Bractwo Świętego } \\
\text { Księcia A. Newskiego Rosyjskiego } \\
\text { Ruchu Ukrainy (2003) }\end{array}$ & - & - & - & Regional \\
\hline $\begin{array}{l}\text { Rosyjsko-Ukraińskie Centrum } \\
\text { Kulturowo-Oświatowe "Rodacy" } \\
\text { m. Winnica (2003) }\end{array}$ & - & - & - & Regional \\
\hline $\begin{array}{l}\text { SRUB Sojusz Rosji, Ukrainy } \\
\text { i Białorusi (2003) }\end{array}$ & - & - & - & Regional \\
\hline $\begin{array}{l}\text { Międzynarodowa Organizacja } \\
\text { "Wierni Kozacy" (2004) }\end{array}$ & $600 / 5$ & - & $\begin{array}{l}\text { "Wierny } \\
\text { Kozak" }\end{array}$ & Nation-wide \\
\hline $\begin{array}{l}\text { Narodowo-Kulturalny Twórczy } \\
\text { Zwiazzek Rosyjskich Dziennikarzy } \\
\text { i Literatów (2004) }\end{array}$ & $350 /-$ & 16 & - & Nation-wide \\
\hline $\begin{array}{l}\text { Ukraińska Akademia Rusycystyki } \\
\text { (2004) }\end{array}$ & - & 20 & - & Nation-wide \\
\hline $\begin{array}{l}\text { Rosyjskie Centrum Kulturalne } \\
\text { Obwodu Rowieńskiego (2005) }\end{array}$ & $2300 / 11$ & 5 & "Glagol" & Regional \\
\hline $\begin{array}{l}\text { Związek Narodu Rosyjskiego } \\
(2005)\end{array}$ & - & - & & Nation-wide \\
\hline $\begin{array}{l}\text { Obwodowa Odesska Organizacja } \\
\text { "Rosyjski Związek Nadczarno- } \\
\text { morza" (2006) }\end{array}$ & $205 /-$ & 10 & $\begin{array}{l}\text { "Naddunajski } \\
\text { Rejon" }\end{array}$ & Regional \\
\hline $\begin{array}{l}\text { Ogólnoukraińska Społeczna Orga- } \\
\text { nizacja Rosyjska Szkoła (2006) }\end{array}$ & - & - & - & Nation-wide \\
\hline $\begin{array}{l}\text { Fundusz Wsparcia Kultury Rosyj- } \\
\text { skiej na Ukrainie (2007) }\end{array}$ & - & - & - & Regional \\
\hline $\begin{array}{l}\text { Ogólnoukraińska Zjednoczona } \\
\text { Organizacja "Wspólnota Rosyjska" } \\
(2007)\end{array}$ & - & - & $\begin{array}{l}\text { „Rosyjska } \\
\text { Prawda” }\end{array}$ & Nation-wide \\
\hline
\end{tabular}


Table 3. cont.

\begin{tabular}{|l|c|c|c|c|}
\hline \multicolumn{1}{|c|}{$\begin{array}{c}\text { Organization / } \\
\text { Year of establishment }\end{array}$} & $\begin{array}{c}\text { No. of ind. } \\
\text { / legal } \\
\text { members }\end{array}$ & Branches & $\begin{array}{c}\text { Publishing } \\
\text { activity } \\
\text { (periodicals) }\end{array}$ & $\begin{array}{c}\text { Territorial } \\
\text { Reach }\end{array}$ \\
\hline $\begin{array}{l}\text { Ogólnoukraińska Organizacja } \\
\text { Ochrony Praw "Ruskojęzyczna } \\
\text { Ukraina" (2009) }\end{array}$ & $55 /-$ & 18 & Nation-wide \\
\hline $\begin{array}{l}\text { Charkowskie Regionalne Towa- } \\
\text { rzystwo "Rus" }\end{array}$ & $514 /-$ & 11 & Regional \\
\hline $\begin{array}{l}\text { Organizacja "Rosyjski Zjazd } \\
\text { Narodowy" }\end{array}$ & - & - & - & Regional \\
\hline Rosyjska Wspólnota m. Charków & - & - & - & Regional \\
\hline $\begin{array}{l}\text { Rosyjska Wspólnota Narodowa } \\
\text { "Rusicz" }\end{array}$ & - & - & - & Regional \\
\hline $\begin{array}{l}\text { Rosyjskie Ziemiaństwo } \\
\text { m. Teodozji }\end{array}$ & - & - & - & Regional \\
\hline $\begin{array}{l}\text { Rosyjski Ruch Młodzieżowy } \\
\text { Ukrainy }\end{array}$ & - & - & - & - \\
\hline Rosyjski Związek Narodowy & - & - & - & Ride \\
\hline
\end{tabular}

Source: author's own elaboration based on: Obŝestvennyje..., 2017; Organizacii Sootečestvennikov za rubežom. Belorus', 2017; Organizacii Sootečestvennikov za rubežom. Moldoviâ, 2017; Russkie..., 2017. 